\title{
Superovulation in red deer (Cervus elaphus) and Père David's deer (Elaphurus davidianus), and fertilization rates following artificial insemination with Père David's deer semen
}

\author{
C. McG. Argo ${ }^{1 *}$, H. N. Jabbour, P. J. Goddard ${ }^{2}$, R. Webb ${ }^{3}$ and \\ A. S. I. Loudon \\ ${ }^{1}$ Institute of Zoology, The Zoological Society of London, Regent's Park, London NW1 4RY, UK; \\ ${ }^{2}$ Macaulay Land Use Research Institute, Aberdeen AB9 2QJ, UK; and ${ }^{3}$ Roslin Institute, \\ Roslin, Midlothian EH25 9PS, UK
}

\begin{abstract}
Two comparative studies were undertaken using adult, female red and Père David's deer to examine the ovulatory response of these animals to a superovulation regimen and fertilization rates following inter- and intraspecific laparoscopic insemination. In Expt 1 six Père David's deer and 12 red deer hinds were treated during the breeding season with an intravaginal progesterone-impregnated controlled internal drug release device (CIDR) for 14 days, with 200 iu pregnant mares' serum gonadotrophin (PMSG) administered $72 \mathrm{~h}$ before the device was withdrawn and eight injections of ovine FSH given at $12 \mathrm{~h}$ intervals starting at the time of PMSG administration. Oestrous behaviour began one day after CIDR device withdrawal (Père David's deer: $24.00 \pm 2.32 \mathrm{~h}$; red deer: $24.60 \pm 2.23 \mathrm{~h}$ ). The duration of oestrus was greater in Père David's deer than in red deer $(17.50 \pm 1.43 \mathrm{~h}$ and $8.25 \pm 3.25 \mathrm{~h}$, respectively, $P<0.001$ ). The peak $\mathrm{LH}$ surge of Père David's deer was $68.65 \pm 4.74 \mathrm{ng} \mathrm{ml}^{-1}$ occurring $29.00 \pm 2.41 \mathrm{~h}$ after removal of the CIDR devices. In comparison, the peak $\mathrm{LH}$ surge in red deer was $17.09 \pm 3.64 \mathrm{ng} \mathrm{ml}^{-1}(P<0.001)$, occurring $24.00 \pm 0.00 \mathrm{~h}$ after CIDR device withdrawal. Pre-surge concentrations of $\mathrm{LH}$ were also greater $(P<0.001)$ in Père David's deer $\left(1.37 \pm 0.11 \mathrm{ng} \mathrm{ml}^{-1}\right)$ than in red deer hinds $\left(0.41 \pm 0.02 \mathrm{ng} \mathrm{ml}^{-1}\right)$. Oestradiol concentrations increased steadily during FSH treatment in both species and reached a maximum of $15.60 \pm 2.22 \mathrm{pg} \mathrm{ml}^{-1}$ at $21.00 \pm 6.20 \mathrm{~h}$ after CIDR device withdrawal in Père David's deer and $26.14 \pm 6.20 \mathrm{pg} \mathrm{ml}^{-1}$ at $20.40 \pm 7.30 \mathrm{~h}$ before CIDR device removal in red deer. The mean number of ovulations recorded was $3.83 \pm 1.22$ (range 1-8) in Père David's deer and 10.80 3.78 (range 4-23) in red deer. In Expt 2, six Père David's deer and six red deer were superovulated with an identical regimen to that described for Expt 1. All hinds were inseminated in utero $36 \mathrm{~h}$ after CIDR device withdrawal with $25 \times 10^{6}$ frozen-thawed Père David's deer spermatozoa. Embryos were recovered by laparotomy 5,6 and 7 days after insemination. A total of six embryos (three Père David's deer $\times$ red deer and three Père David's deer $\times$ Père David's deer) were collected. One pregnancy was confirmed following the transfer of all embryos to synchronized red deer recipients. This pregnancy was terminated naturally between days 70 and 78 . This is the first report of an interspecific transfer of hybrid embryos in a cervid and of the comparative superovulation response in two related species. The results indicate that treatment with PMSG and ovine FSH can be used in embryo transfer programmes for these species. However, in this study there were low inter-specific fertilization rates and transferred hybrid embryos failed to develop to term.
\end{abstract}

\section{Introduction}

Interest in the application of reproductive technology in cervid species has greatly increased over the past decade. Artificial

*Present address: Department of Biological and Earth Sciences, Liverpool John Moores University, Liverpool L3 3AF, UK.

Revised manuscript received I September 1993. insemination with the purpose of rapidly disseminating valuable genetic material from male red and fallow deer has had a widespread application in New Zealand (Kelly and Moore, 1981; Asher et al., 1988a). Similarly, superovulation and subsequent embryo transfer programmes have been attempted in these species for the rapid dissemination of female genetic material (Bringans, 1987; Fennessy et al., 1989; Jabbour et al., 
1992) but the inherent complexities of these protocols have limited their widespread application.

The application of embryo transfer is of importance to conservation biology. Of the 36 species of deer, half are classified as vulnerable or endangered (IUCN, 1988). The application of superovulation, artificial insemination and interspecific transfer of embryos to compatible surrogate recipients may assist in rapidly increasing the numbers of certain vulnerable species.

Attempts at hybridization in deer, whether by artificial insemination or natural mating, have been accompanied by reduced fertility. Pregnancy rates of red deer are markedly lower following insemination with Père David's deer than with red deer semen (Asher et al., 1988b). Similar effects have been noted when red deer have been inseminated with a closely related subspecies, the wapiti (Haigh and Bowen, 1991). The following study was designed to compare the ovarian response of physically distinct but karyotypically similar species, the European red deer and Chinese Père David's deer, to superovulatory treatment with pregnant mares' serum gonadotrophin (PMSG) and ovine FSH (o-FSH). Moreover, the fertilization rates following insemination with inter- or intraspecific semen were determined and pregnancy rates established following embryo transfer to red deer hinds.

\section{Materials and Methods}

\section{Animals and collection of blood samples before treatment}

In Expt 1, 18 mature ( $>2$ years old) Père David's $(n=6)$ and red deer $(n=12)$ hinds were used to characterize the endocrine, behavioural and ovarian responses to treatment with PMSG and o-FSH. In Expt 2, 12 mature ( $<2$ years old) Père David's deer $(n=6)$ and red deer $(n=6)$ designated as potential embryo donors were treated with the same PMSG/o-FSH regimen as in Expt 1. Mean body weights for Père David's and red deer were $169.5 \pm 5.4$ (mean $\pm \mathrm{SEM}, \quad n=12$ ) and $92.14 \pm 1.5 \mathrm{~kg}(n=18, P<0.001)$, respectively. A further 12 red deer hinds were designated as embryo transfer recipients. All animals were hand-reared, tame and used to repeated handling. Throughout the experiments the hinds grazed at pasture, or were maintained in yards and fed grass silage, and supplemented with barley and soya bean meal. Blood samples were collected twice a week for progesterone determination for 2 months before the experiment to ensure that all animals were undergoing repeated oestrous cycles by the start of the experiment (McLeod et al., 1991; Argo and Loudon, 1992). Samples were collected by jugular venepuncture under manual restraint. Behavioural oestrus was recorded as the response to manual pressure on the hind quarters as previously described (Curlewis et al., 1988; Argo and Loudon, 1992). In both species, hand-reared hinds exhibit very conspicuous oestrous behaviour to human handlers.

\section{Experiment 1: ovarian and endocrine response to PMSG and o- $F S H$}

All hinds were treated with intravaginal controlled internal drug release devices (CIDR; type G, $9 \%$ progesterone, AHI
Plastic Moulding Company, Hamilton) on November 11, 1991. On the basis of interspecific weight differences, hinds were fitted with one (red deer) or two (Père David's deer) CIDR devices. At this time both species were reproductively active but the red deer and Père David's deer were in the early and late phases of their respective breeding seasons. CIDR devices were replaced on day 7 and finally withdrawn at $23: 00 \mathrm{~h}$ on 24 November (Père David's deer) and 02:00 h on 25 November (red deer). The hour of CIDR device withdrawal was designated as time zero $\left(t_{0}\right)$ for each species. Five days before CIDR device withdrawal (19 November) all hinds were treated i.m. with $25 \mu \mathrm{g}$ of cloprostenol, a prostaglandin analogue (Estrumate; Cooper's Animal Health, Crewe). Each hind received 200 iu PMSG (Intervet, UK Ltd, Cambridge) $72 \mathrm{~h}$ before CIDR device removal. Ovine-FSH (Ovagen: Immunochemical Products Ltd, Auckland) was administered in eight $0.625 \mathrm{mg}$ injections at intervals of $12 \mathrm{~h}$ starting at the time of PMSG administration and finishing $12 \mathrm{~h}$ after CIDR device removal.

Blood samples were collected from a total of 12 (Père David's deer, $n=6$; red deer, $n=6$ ) hinds at intervals of $12 \mathrm{~h}$ for 6 days starting $12 \mathrm{~h}$ before PMSG treatment for determination of oestradiol profiles and at intervals of $3 \mathrm{~h}$ for $60 \mathrm{~h}$ starting from the time of CIDR device withdrawal for determination of $\mathrm{LH}$ and progesterone profiles. Blood samples were centrifuged at $2400 \mathrm{~g}$ for $10 \mathrm{~min}$. Plasma was aspirated and stored at $-20^{\circ} \mathrm{C}$ until required for analysis. At the time of collection of blood samples, each animal was checked for evidence of behavioural oestrus. The ovarian response of all 18 deer to exogenous gonadotrophin treatment was determined by laparoscopy (Asher et al., 1990) under general anaesthesia: $0.5 \mathrm{mg}$ xylazine hydrochloride $\mathrm{kg}^{-1}$ liveweight (Rompun: Bayer Leverkusen) and $0.01 \mathrm{~g}$ sodium thiopentone $\mathrm{kg}^{-1}$ liveweight (Intraval Sodium: May \& Baker Ltd, Dagenham) $108 \mathrm{~h}$ after CIDR device removal in each species (i.e. 29 November). Numbers of corpora lutea and large $(>3 \mathrm{~mm})$ unruptured follicles were recorded.

\section{Experiment 2: embryo recovery and transfer}

All hinds were treated with CIDR devices and a single injection of cloprostenol as described in Expt 1. Five days before CIDR device withdrawal, the animals were randomly allocated to either embryo donor or recipient groups. The hinds in the donor group (Père David's deer, $n=6$ and red deer, $n=6$ ) were treated with the same PMSG/o-FSH regimen as described for Expt 1. CIDR devices were withdrawn at 23:00 h (26 November) and 02:00 h (27 November) from all Père David's and red deer hinds, respectively.

Semen was collected by electroejaculation from a Père David's deer stag during the previous breeding season (Asher et al., 1988b). The ejaculate was extended to a concentration of $100 \times 10^{6}$ spermatozoa $\mathrm{ml}^{-1}$ in a diluent containing $2.9 \%$ sodium citrate, $20 \%$ egg yolk and $8 \%$ glycerol, loaded into $0.25 \mathrm{ml}$ straws, frozen in liquid nitrogen vapour and stored in liquid nitrogen until required for insemination. Only semen from straws with a post-thaw motility of $>40 \%$ were used in the experiment. Hinds in the donor group were inseminated by laparoscopy (Asher et al., 1988b) under general anaesthesia, 


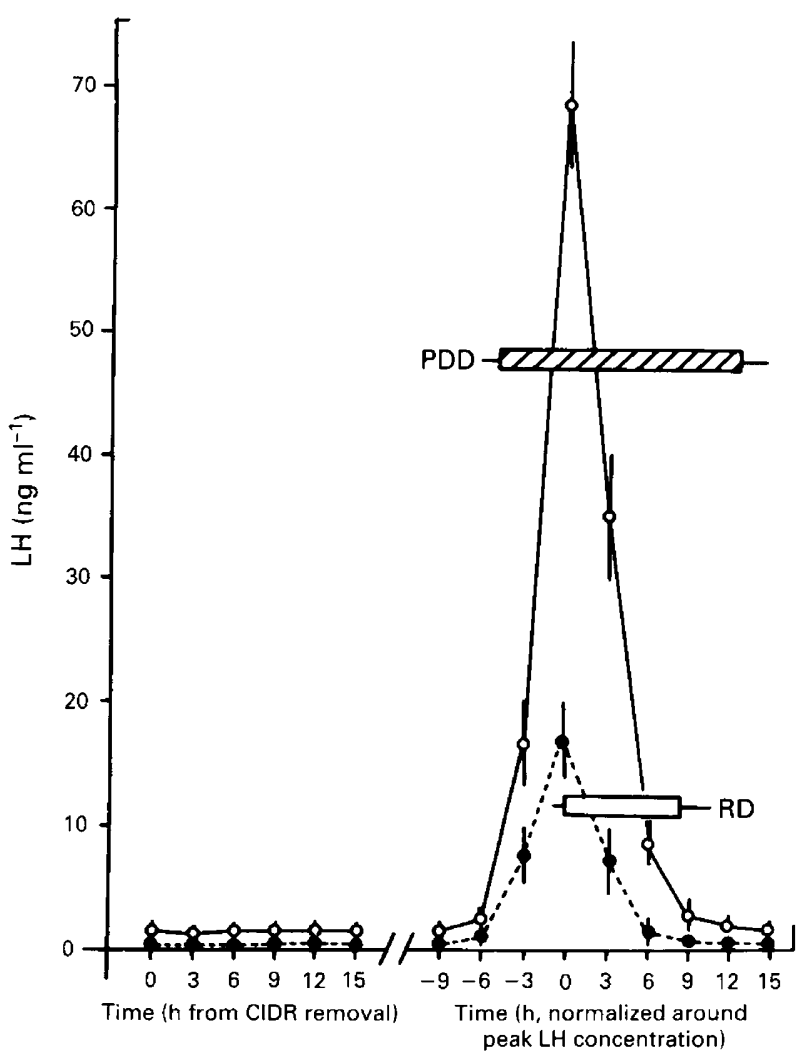

Fig. 1. Changes in the mean LH concentrations of (O) red deer (RD) hinds $(n=4)$ and $(O)$ Père David's deer PDD hinds $(n=6)$ during the $15 \mathrm{~h}$ following controlled internal drug release (CIDR) device removal. Mean changes in concentration of $\mathrm{LH}$ during the $\mathrm{LH}$ surge have been normalized around the surge peak. Vertical lines represent the SEM. Horizontal bars represent the duration of behavioural oestrus, normalized with respect to the LH surge peak, for red deer $(n=5)$ and Père David's deer $(n=6)$, respectively. Horizontal lines represent the SEM of the times of onset and termination of oestrous behaviour.

$36 \mathrm{~h}$ after CIDR device withdrawal. In all animals, a total of $25 \times 10^{6}$ spermatozoa (one straw) was divided equally between both uterine horns. Hinds were housed overnight in their pretreatment groups following insemination.

Embryo recovery was attempted by flushing both uterine horns at laparotomy under general anaesthesia on either days 5,6 or 7 after artificial insemination as described by Jabbour and Evans (1991). The numbers of corpora lutea and large follicles were recorded at the time of embryo recovery. Embryos and ova were assessed by examination under a stereomicroscope, and numbers and stages of development were recorded. Single embryos were transferred by laparoscopy into the uterine horn ipsilateral to the active corpora lutea of the synchronized recipient hinds. All hinds were grouphoused for a week following surgery. Recipient hinds were scanned for pregnancy determination by transrectal ultrasonography 40 and 70 days after embryo transfer.

\section{Radioimmunoassays}

Progesterone was measured in a direct radioimmunoassay as previously described for Père David's deer (McLeod et al., 1991) and red deer (Argo and Loudon, 1992). The antibody was raised in sheep against progesterone $11 \alpha$-hemisuccinate-BSA (HP/S/645-111A, NETRIA, St Bartholomew's Hospital, London) and used at a final concentration of 1:18 000. The antisera crossreacted with 11 $\beta$-hydroxyprogesterone, $11 \alpha$-hydroxyprogesterone, $16 \alpha$ hydroxprogesterone, $5 \alpha$-pregnanedione, $5 \beta$-pregnanedione and 20a-dihydroprogesterone at 208.3, 80.6, 9.0, 8.3, 3.2 and $2.4 \%$, respectively. Assay sensitivity was $0.8 \mathrm{ng} \mathrm{ml}^{-1}$ and intra- and interassay coefficients of variation were $7.6 \%$ and $5.1 \%$ at 0.80 and $1.72 \mathrm{ng} \mathrm{ml}^{-1}$, respectively.

LH was determined using the heterologous ovine doubleantibody radioimmunoassay (rabbit, anti-ovine LH serum, R07/6) previously described by Loudon et al. (1990). The assay sensitivity was $0.2 \mathrm{ng} \mathrm{NIH-LH-S24}$ equivalents $\mathrm{ml}^{-1}$ plasma, and the intra- and interassay coefficients of variation at $1.12 \mathrm{ng}$ $\mathrm{ml}^{-1}$ were $8.9 \%$ and $9.4 \%$, respectively.

Oestradiol was determined in an extraction assay as described by Webb et al. (1985). The affinity extraction step used sheep, oestradiol antisera (26.9.80). The oestradiol antisera used in the radioimmunoassay was raised in rabbits, against $17 \beta$-oestradiol-11 $\beta$-succinyl-BSA (R48, 22.6.83) and used at a final concentration of 1:40000. The antisera crossreacted with oestrone, oestriol and testosterone at 16,3 and $1.2 \%$, respectively. The assay sensitivity was $0.95 \mathrm{pg} \mathrm{ml}^{-1}$ and intra- and interassay coefficients of variation were $6.3 \%$ and $13.1 \%$, at 9.10 and $3.19 \mathrm{pg} \mathrm{ml}^{-1}$, respectively.

\section{Statistical analysis}

All data are presented as means $\pm \mathrm{SE}$. Comparisons within and between groups were made with either paired or unpaired Student's $t$ tests, respectively, with degrees of freedom adjusted for inequality in the variance of means.

\section{Results}

Experiment 1: ovarian and endocrine response to PMSG and o-FSH

After removal of the CIDR devices five of the six red deer hinds displayed oestrous behaviour but only four displayed an LH surge. Each of the six Père David's deer displayed both oestrous behaviour and an LH surge. At laparoscopy, the red deer hind that failed to show oestrous behaviour had very small and inactive ovaries and hence was excluded from further analyses. The mean pre-surge $\mathrm{LH}$ concentrations ( $1.37 \pm 0.11 \mathrm{ng} \mathrm{ml}^{-1}$ versus $0.41 \pm 0.02 \mathrm{ng} \mathrm{ml}^{-1}$ ) and mean peak surge LH concentrations $\left(68.65 \pm 4.74 \mathrm{ng} \mathrm{ml}^{-1}\right.$ versus $17.09 \pm 3.64 \mathrm{ng} \mathrm{ml}^{-1}$ ) were significantly higher in Père David's deer than in red deer $\left(t_{5}=16.59, P<0.001 ; t_{8}=7.82\right.$, $P<0.001)$. Although the duration of the $\mathrm{LH}$ surge was similar in both species (Père David's deer: $16.75 \mathrm{~h}$; red deer: $15.80 \mathrm{~h}$ ), the peak of the LH surge did not occur until $5 \mathrm{~h}$ later in the Père David's deer $(29.00 \pm 2.41 \mathrm{~h}$; and in red deer, $24.00 \pm 0.00 \mathrm{~h})$. Hinds of both species displayed oestrous behaviour at the same time relative to CIDR device withdrawal (Père David's deer $24.00 \pm 2.32 \mathrm{~h}$; red deer: $24.60 \pm 2.23 \mathrm{~h}$ ). The onset of behavioural oestrus coincided with the peak of the LH surge in 


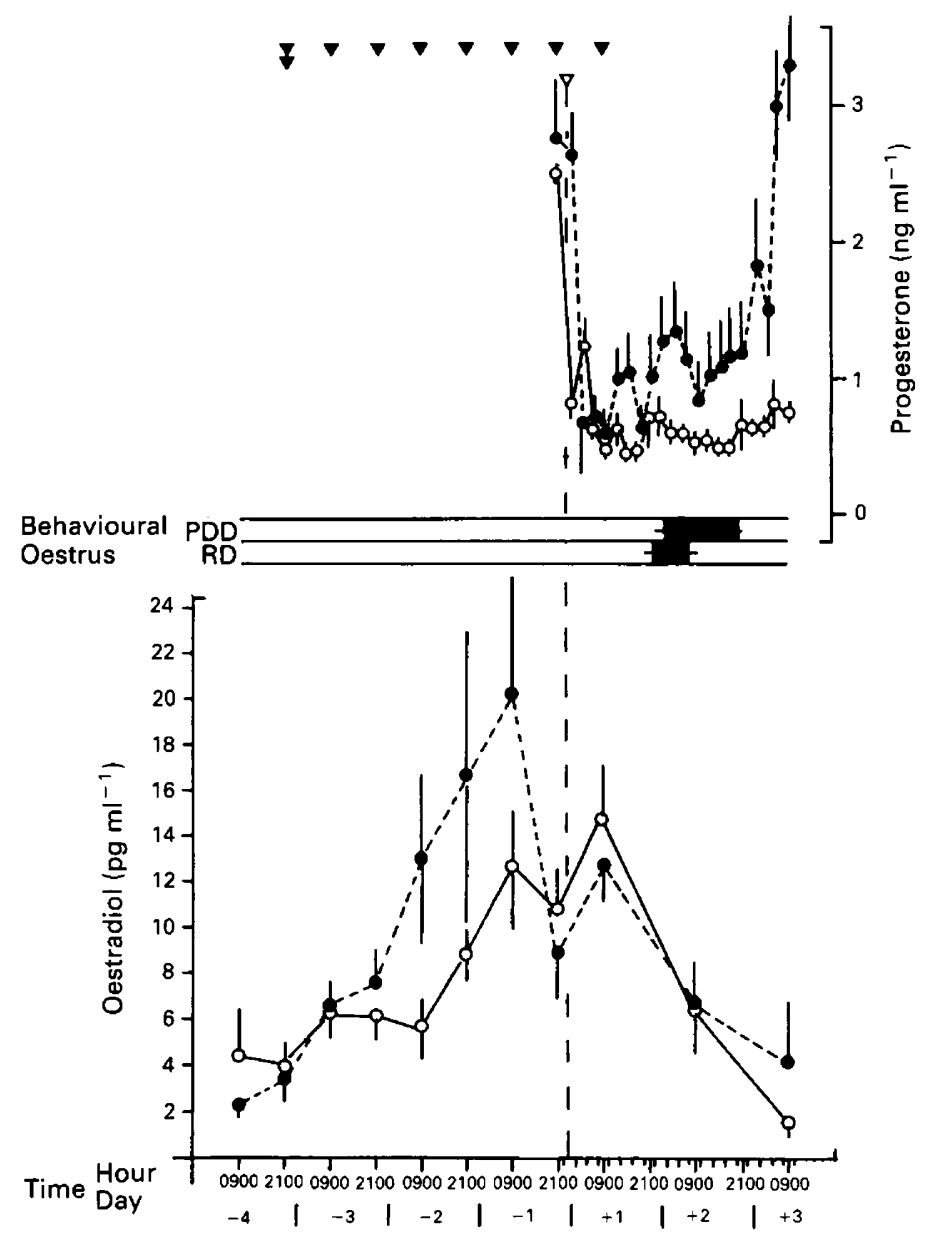

Fig. 2. Changes in mean plasma steroid concentrations over the final 4 days of progesterone priming, during which gonadotrophin treatment was given, and the 3 days following controlled internal drug release (CIDR) device withdrawal in $(O)$ red deer $(R D)(n=5)$, and (O) Père David's deer (PDD) $(n=6)$. Vertical lines represent the SEM. Horizontal bars represent the relative mean duration of behavioural oestrus in both species. The double solid arrow indicates the initial combined injection of pregnant mares' serum gonadotrophin (PMSG) and ovine FSH (o-FSH), and the single arrows represent subsequent o-FSH treatments. The open arrow and vertical broken line indicate the time of CIDR device withdrawal.

red deer and occurred $5 \mathrm{~h}$ before peak $\mathrm{LH}$ values in Père David's deer (Fig. 1). The duration of oestrus was longer in Père David's deer $(17.50 \pm 1.43$ versus $8.25 \pm 3.25 \mathrm{~h}$ for Père David's deer and red deer, respectively, $t_{9}=3.8, P<0.001$, Fig. 1).

In both species, there were significant changes in plasma concentrations of oestradiol during the period of FSH treatment (Père David's deer, $t_{8}=-2.74, P<0.05$; red deer, $t_{8}=-3.52, P<0.01$, Fig. 2). Mean oestradiol concentrations increased in Père David's deer from $4.5 \pm 2.9 \mathrm{pg} \mathrm{ml}^{-1}$ to reach a peak of $14.9 \pm 2.5 \mathrm{pg} \mathrm{ml}^{-1}$, coincident with the final FSH injection and $10 \mathrm{~h}$ after CIDR device withdrawal. In the red deer, mean oestradiol concentrations increased from $2.1 \pm 0.5 \mathrm{pg} \mathrm{ml}^{-1}$ to $20.2 \pm 5.2 \mathrm{pg} \mathrm{ml}^{-1} 17 \mathrm{~h}$ before CIDR device removal.
Plasma progesterone concentrations did not exhibit a significant change during the $60 \mathrm{~h}$ following CIDR device removal in Père David's deer hinds $\left(t_{5}=-2.81\right.$, ns). Over the same period, progesterone concentrations in red deer increased significantly from $0.7 \pm 0.08 \mathrm{ng} \mathrm{ml}^{-1}$ to $3.3 \pm 0.98 \mathrm{ng} \mathrm{ml}^{-1}$ $\left(t_{5}=-3.38, P<0.05\right.$, Fig. 2).

All 11 red deer hinds and four Père David's deer hinds had multiple ovulations following PMSG/o-FSH treatment (Table $1)$. In red deer $(n=11), 2.55 \pm 0.86$ large follicles and $9.82 \pm 2.09$ corpora lutea were observed, giving a total ovarian response (large follicles plus corpora lutea) of $12.37 \pm 2.36$. In Père David's deer $(n=6) 1.00 \pm 0.20$ large follicles and $3.83 \pm 1.80$ corpora lutea were observed with a total ovarian response of $4.83 \pm 1$ 1.9. The ovulation rate in both species was $79 \%$ of the total ovarian response. 
Table 1. The concentration and timing of the preovulatory oestradiol peak, with respect to withdrawal of the controlled internal drug release devices and corresponding ovarian response in red deer and Père David's deer

\begin{tabular}{|c|c|c|c|c|c|c|}
\hline \multirow[b]{2}{*}{ Deer } & & \multirow{2}{*}{$\begin{array}{c}\text { Time }(h) \text { of } \\
\text { peak oestradiol } \\
\text { concentration }\end{array}$} & \multirow{2}{*}{$\begin{array}{l}\text { Oestradiol peak } \\
\text { concentration } \\
\left(\text { pg ml }{ }^{-1}\right)\end{array}$} & \multicolumn{3}{|c|}{ Ovarian response } \\
\hline & & & & $\mathrm{LF}$ & $\mathrm{CL}$ & TOR \\
\hline \multirow[t]{3}{*}{ Red deer $(n=5)$} & Mean & $-20.4^{\mathrm{a}^{*}}$ & $26.14^{c}$ & $2.80^{\mathrm{d}}$ & $10.80^{f}$ & $13.6^{\mathrm{h}}$ \\
\hline & SEM & 7.30 & 6.20 & 0.58 & 3.73 & 4.30 \\
\hline & Range & $-42-6$ & $10.0-43.0$ & $2-5$ & $4-23$ & $6-28$ \\
\hline \multirow[t]{3}{*}{ Père David's deer $(n=6)$} & Mean & $21.0^{\mathrm{b}}$ & $15.6^{c}$ & $1.00^{e}$ & $3.83^{\mathrm{g}}$ & $4.83^{\mathrm{i}}$ \\
\hline & SEM & 6.20 & 2.22 & 0.40 & 1.22 & 1.30 \\
\hline & Range & $-3-45$ & $10-24$ & $0-2$ & $1-8$ & $1-9$ \\
\hline
\end{tabular}

${ }^{*}$ Values with different superscripts are significantly different $(P<0.05)$.

LF: large follicles; $\mathrm{CL}$ : corpora lutea; TOR: total ovarian response.

Despite differences in the ovarian response and oestradiol concentrations of individuals, there was little difference in the timing of the LH surge and onset of sexual behaviour within each species. Endocrine profiles for two red deer hinds are shown in Fig. 3. In the case of hind 1 (total ovarian response of 19), oestradiol concentrations were maximal after CIDR withdrawal and progesterone concentrations did not increase for $56 \mathrm{~h}$. This result contrasts with hind 2 (total ovarian response of 28), in which oestradiol concentrations were maximal $24 \mathrm{~h}$ before CIDR removal and increasing progesterone concentrations were evident from the time of CIDR withdrawal. In both animals the LH surge and behavioural oestrus occurred at the same time relative to removal of the CIDR device.

\section{Experiment 2: embryo recovery and transfer}

Data on the ovarian response and embryo recovery rates following superovulation are shown (Table 2). The mean total ovarian response was $7.00 \pm 2.59$ and $5.00 \pm 1.65$ for red deer and Père David's deer, respectively. From the red deer, a total of 11 ova and three hybrid embryos (two-cell, eight-cell and a blastocyst) were recovered from two of the six hinds. In Père David's deer, two ova and three embryos (eight-cell, approximately 32-cell and a blastocyst) were recovered from two out of six hinds. After transfer, one pregnancy was confirmed and maintained until between days 70 and 78 , when natural termination of the pregnancy occurred.

\section{Discussion}

Treatment with PMSG and o-FSH was successful in inducing multiple ovulations in Père David's deer and red deer. The use of comparatively low doses of both gonadotrophins in combination is reputed to be more suitable than administering either gonadotrophin separately. In sheep (Jabbour and Evans, 1991) and fallow deer (Thompson and Asher, 1988) large doses of PMSG induce a high proportion of large follicles that fail to rupture and FSH alone results in a proportion of animals that fail to respond to treatment. The ovulatory response of red deer in this study was similar to that shown by Jabbour et al. (1992) where the optimum superovulatory response was observed following treatment of red deer hinds with an identical gonadotrophin regimen. There are no comparable data for Père David's deer.

The reasons for the interspecies differences in the ovarian response in this study are unclear. These may be due to variations in body size (the same absolute doses were used) or to the fact that the study was conducted at the early part of the breeding season in red deer and towards the end of the breeding season in Père David's deer. In sheep, there have been suggestions that the response to a given dose of PMSG is affected by the time of the year that PMSG is administered (Braden et al., 1966; Gherardi and Lindsay, 1980). These latter authors observed the greatest response in March and the lowest one in September in the southern hemisphere. Lamond (1962) suggested that this may be due to a change in the sensitivity of the neuroendocrine systems controlling ovarian activity. Although there are no published data on changes in response to gonadotrophins in deer across the breeding season, Curlewis et al. (1991) have demonstrated a significant seasonal change in the $\mathrm{LH}$ response to exogenous $\mathrm{GnRH}$ during the 7-month anoestrous period of Père David's deer.

Notwithstanding the relatively low frequency of sampling (every $12 \mathrm{~h}$ ), it is clear that oestrogen secretion peaked at or shortly before the time of progesterone withdrawal. The increase in oestrogen concentration in both species during treatment with o-FSH indicates that follicular development is not inhibited by exogenous progesterone. In both species, there was an approximate $24 \mathrm{~h}$ delay from progesterone withdrawal to the onset of behavioural oestrus and the $\mathrm{LH}$ surge, irrespective of the individual differences in the oestrogen profiles. This finding suggests that in the hind, progesterone inhibits the positive feedback of oestrogen on $\mathrm{LH}$ as well as blocking the oestrogen-stimulated expression of oestrous behaviour. In superovulated ewes, there is a dissociation between behavioural oestrus and the pre-ovulatory $\mathrm{LH}$ surge (Willadsen, 1979). In contrast, in the study reported here, the period of overt oestrous behaviour occurs at about the same time as the LH surge, as previously shown for natural oestrus 

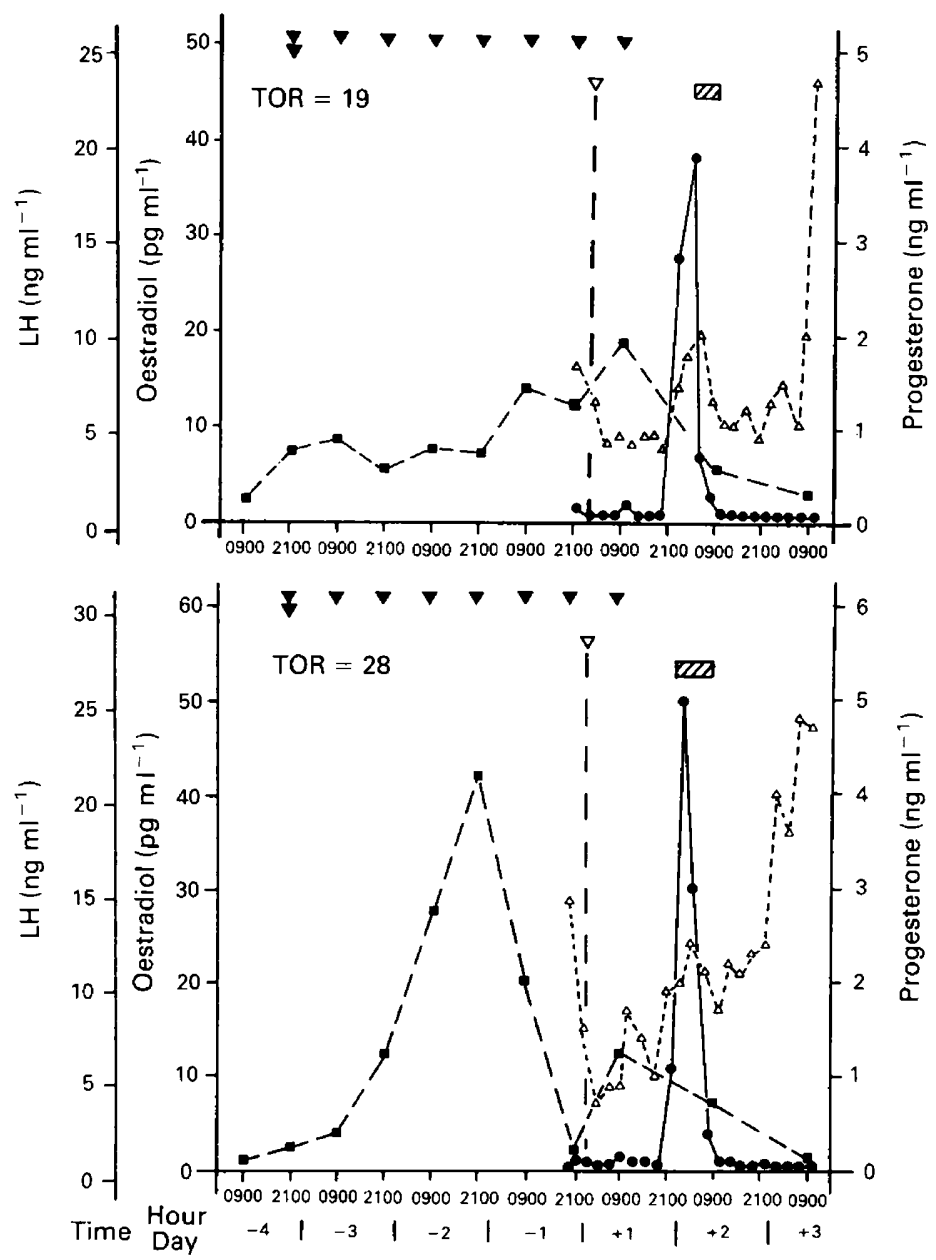

Fig. 3. Endocrine profiles of two superovulated red deer hinds, during the 4 days before and the 3 days after controlled internal drug release (CIDR) device removal, illustrating divergent ovarian responses to identical gonadotrophin treatments. Oestradiol $(\boldsymbol{\square})$, progesterone $(\triangle)$ and $L H(\bullet)$. Horizontal bars represent behavioural oestrus. Solid arrows represent the times of ovine-FSH (o-FSH) treatment. The double solid arrow indicates the initial combined PMSG/o-FSH injection. The open arrow and vertical broken line represent the time of CIDR device removal. TOR: total ovarian response.

in red deer (Argo and Loudon, 1992) and in monovulating and superovulating red deer (Asher et al., 1992).

On the basis of a rapid decline in oestrogen concentration, it is probable that ovulation in some red deer hinds commenced before CIDR device withdrawal. This is substantiated by a rapid increase in the mean progesterone profiles during the $60 \mathrm{~h}$ after CIDR device removal, indicating an early onset of luteal function. Ovulations during the progesterone priming period must have occurred in the absence of an endogenous $\mathrm{LH}$ surge. $\mathrm{LH}$ concentrations remained low during progesterone treatment. These results are consistent with the observations in fallow deer (Jabbour et al., 1993a) and goats (Cameron and Batt, 1991) in which ovulations were observed in animals that failed to exhibit an LH surge following treatment with PMSG. This may be a result of direct action of PMSG at the ovarian level. PMSG has potent LH-like activity (Farmer and Papkoff, 1979) and has been demonstrated to have a half-life far in excess of endogenous LH in other ruminants (such as goat, Armstrong et al., 1983; and sheep, Mclntosh et al., 1975). The later onset of the decline in oestrogen concentration in Père David's deer suggests that ovulation was probably initiated by the endogenous LH surge in this species.

Artificial insemination with frozen-thawed semen has been used for inter-subspecific and inter-specific hybridization of deer (Asher et al., 1988b; Asher et al., 1993; Haigh and Bowen, 1991; Jabbour et al., 1993b), although in interspecific hybridization fertility is very low. For instance, a calving percentage of 7.8 was recorded following intrauterine insemination of red deer hinds with Père David's deer semen (Asher et al., 1988b). In the study reported here, ova recovery rates were low in both species (red deer, $43.15 \%$; Père David's deer, 29.33\%). This may be attributed to secretion of high concentrations of 
Table 2. The day of uterine flushing after artificial insemination, the ovarian response, ova and embryos collected, and pregnancies arising from the transfer of all embryos in red deer and Père David's deer

\begin{tabular}{|c|c|c|c|c|c|c|}
\hline Hind No. & Day & LF & $\mathrm{CL}$ & Ova & Embryos & Pregnancy \\
\hline RD21 & 5 & 2 & 1 & - & - & - \\
\hline $\mathrm{RD} 22$ & 5 & 4 & 3 & 2 & 1 ( 2 cell $)$ & \\
\hline RD53 & 6 & $I$ & 1 & - & - & - \\
\hline RD76 & 6 & 0 & 19 & 7 & $\begin{array}{l}2(8 \text { cell }) \\
\text { (blastocyst) }\end{array}$ & $\begin{array}{c}- \\
70-78 \text { days }\end{array}$ \\
\hline RD77 & 7 & 3 & 0 & - & - & - \\
\hline RD80 & 7 & 0 & 8 & 2 & - & - \\
\hline Mean & & 1.67 & 5.33 & 1.80 & 0.5 & \\
\hline $\mathrm{SE}$ & & 0.67 & 2.97 & 1.11 & 0.34 & \\
\hline PDD2 & 5 & 0 & 4 & - & $\begin{array}{c}2(8 \text { cell }) \\
(32 \text { cell })\end{array}$ & - \\
\hline PDD3 & 5 & 0 & 1 & - & - & - \\
\hline PDD7 & 6 & 10 & 1 & - & - & - \\
\hline PDD8 & 6 & 3 & 6 & - & - & - \\
\hline PDD5 & 7 & 0 & 3 & - & I (blastocyst) & 一 \\
\hline PDD17 & 7 & 0 & 2 & 2 & - & - \\
\hline Mean & & 2.17 & 2.83 & 0.33 & 0.5 & \\
\hline $\mathrm{SE}$ & & 1.64 & 0.79 & 0.3 & & \\
\hline
\end{tabular}

Group mean and individual results are shown for the red deer (RD, $n=6$ ) and Père David's deer (PDD, $n=6$ ) inseminated with frozen-thawed Père David's deer semen in Experiment 2.

CL: corpora lutea; LF: large follices.

oestrogen, which have been shown to disrupt the biochemical maturation of oocytes in ewes (Moor et al., 1985) and also accelerate the transport of gametes in the female reproductive tract. Ova, entering the uterus prematurely, face a hostile environment and may be expelled promptly (Whyman and Moore, 1980). The embryos recovered were at different stages of development, suggesting that the oviductal and uterine environments were not conducive to proper development. The failure of transferred embryos to implant and the natural termination of the one established pregnancy may have been caused by a mismatch between the stage of development of the embryo and the uterine environment of the recipient animals. Problems of genetic incompatibility, implicit in the retarded development of hybrid murine embryos (Frels et al., 1980), inappropriate interactions between trophoblast and endometrium, and immunological involvement (Anderson, 1988) must also be considered as potential causes of embryonic death.

In conclusion, this study has demonstrated that superovulation and embryo transfer technology can be used to establish interspecific pregnancy in cervids. The next step is to understand the mechanisms underlying survival following interspecific embryo transfer.

The authors acknowledge their gratitude for the assistance given by L. Wilton, C. Layram, G. Baxter, J. Blanco, J. Barnett, B. Hastings, A. Hartley, A. McDonald and C. Tudge. Financial support was granted by the Ministry of Agriculture, Fisheries and Food. They also thank the National Hormone and Pituitary Program who provided the purified LH used in the radioimmunoassay.

\section{References}

Anderson GB (1988) Interspecific pregnancy: barriers and prospects Biology of Reproduction 38 I-15

Argo CMcG and Loudon ASI (1992) Effect of age and time of day on the surge in luteinizing hormone, behavioural oestrus and mating in red deer hinds (Cervus elaphus) Journal of Reproduction and Fertility 96 667-672

Armstrong DT, Pfitzner AP, Warnes GM, Ralph MM and Seamark RF (1983) Endocrine response of goats after induction of superovulation with PMSG and FSH Joumal of Reproduction and Fertility 67 395-401

Asher GW, Adam JL, James RW and Barnes D (1988a) Artificial insemination of farmed fallow deer (Dama dama): fixed time insemination at a synchronised oestrus Animal Production 47 487-492

Asher GW, Adam JL, Ottway W, Bowmar P, Van Reenan G, Mackintosh CJ and Dratch P (1988b) Hybridization of Père David's deer (Elaphurus davidianus) and red deer (Cervus elaphus) by artificial insemination journal of Zoology 215 197-203

Asher GW, Kraemer DC, Magyar SJ, Brunner M, Moerbe R and Giaquinto $\mathbf{M}$ (1990) Intrauterine insemination of farmed fallow deer (Dama dama) with frozen-thawed semen via laparoscopy Theriogenology 34 569-577

Asher GW, Fisher MW, Jabbour HN, Smith JF, Mulley RC, Morrow CJ, Veldhuizen FA and Langridge M (1992) Relationships between the onset of oestrus, the preovulatory surge in luteinizing hormone and ovulation following oestrus synchronization and superovulation in farmed red deer (Cervus elaphus) journal of Reproduction and Fertility 96 261-273

Asher GW, Morrow CJ, Jabbour HN, Mulley RC, Veldhuizen, FA and Langridge M (1993) Laparoscopic intrauterine insemination of fallow deer with frozenthawed or fresh semen. New Zealand Veterinary Journal 40 8-14

Braden AW, Lamond DR and Radford HM (1966) The control of the time of ovulation in sheep Australian Journal of Agricultural Science 11 389-401

Bringans M (1987) Embryo transfer in deer Proceedings of the Deer Course for Veterinarians (Deer Branch of the New Zealand Veterinary Association) 4 $45-52$

Cameron AWN and Batt PA (1991) PMSG may directly stimulate ovulation in female goats Animal Reproduction Science 25 233-239 
Curlewis JD, Loudon ASI and Coleman APM (1988) Oestrous cycles and the breeding season of the Père David's deer hind (Elaphurus davidianus) Journal of Reproduction and Fertility 82 119-126

Curlewis JD, McLeod BJ and Loudon ASI (1991) LH secretion and response to GnRH during seasonal anoestrus of the Père David's deer hind (Elaphurus davidianus) Journal of Reproduction and Fertility 91 131-138

Farmer SW and Papkoff H (1979) Immunochemical studies with pregnant mare serum gonadotrophin Biology of Reproduction 21 425-431

Fennessey PF, Fisher MW, Shackell GH and Mackintosh CG (1989) Superovulation and embryo recovery in red deer (Cervus elaphus) hinds Theriogenology 32 877-883

Frels WI, Rossant J and Chapman VM (1980) Intrinsic and extrinsic factors affecting the viability of Mus caroli $\times$ Mus musculus hybrid embryos Joumal of Reproduction and Fertility 59 387-392

Gherardi PB and Lindsay DR (1980) The effect of season on the ovulatory response of Merino ewes to serum from pregnant ewes joumal of Reproduction and Fertility 60 425-429

Haigh JC and Bowen G (1991) Artificial insemination of red deer (Cerous elaphus) with frozen-thawed wapiti semen Journal of Reproduction and Fertility 93 119-128

IUCN (1988) 1988 IUCN red list of threatened animals. IUCN, Gland

Jabbour HN and Evans G (1991) Ovarian and endocrine responses of Merino ewes to treatment with PMSG and/or FSH-P Animal Reproduction Science 26 93-106

Jabbour HN, Asher GW, Thompson JGE, Tervit HR and Morrow CJ (1992) Studies on superovulation and embryo recovery in farmed red and fallow deer. In The Biology of Deer pp 357 Ed. RD Brown. Springer-Verlag, Berlin

Jabbour HN, Veldhuizen FA, Green G and Asher GW (1993a) Endocrine responses and conception rates in fallow deer (Dama dama) following oestrous synchronization and cervical insemination with fresh or frozenthawed spermatozoa Journal of Reproduction and Fertility 98 495-502

Jabbour HN, Argo CMcG, Brinklow BB, Hooton J and Loudon ASI (1993b) Conception rates following intrauterine insemination of European (Dama dama dama) fallow deer does with fresh or frozen-thawed Mesopotamian
(Dama dama mesopotamica) fallow deer spermatozoa Joumal of Zoology 230 379-384

Kelly RW and Moore GH (1981) Artificial insemination of red deer New Zealand Ministry of Agriculture, Agricultural Research Division (Annual Report)

Lamond DR (1962) Effect of season on hormonally induced ovulation in Merino ewes Journal of Reproduction and Fertility 4 111-120

Loudon ASI, McLeod BJ and Curlewis JD (1990) Pulsatile secretion of LH during the periovulatory and luteal phases of the oestrous cycle in the Père David's deer hind (Elaphurus davidianus) Journal of Reproduction and Fertility $\mathbf{8 9}$ 663-670

McIntosh JEA, Moor RM and Allen WR (1975) Pregnant mare serum gonadotrophin rate of clearance from the circulation of the sheep Joumal of Reproduction and Fertility 44 95-100

McLeod BJ, Brinklow BR, Curlewis JD and Loudon ASI (1991) Efficacy of intermittent or continuous administration of $\mathrm{GnRH}$ in inducing ovulation in early and late seasonal anoestrus in the Père David's deer hind (Elaphurus davidianus) Journal of Reproduction and Fertility $91229-238$

Moor RM, Osborn JC and Crosby IM (1985) Gonadotrophin-induced abnormalities in sheep oocytes after superovulation Journal of Reproduction and Fertility 74 167-172

Thompson JGE and Asher GW (1988) Superovulation and ova recovery in farmed fallow deer (Dama dama) Proceedings of the Australian Society for Reproductive Biology 204

Webb R, Baxter G, McBride D, Nordblom GD and Shaw NPK (1985) The measurement of testosterone and oestradiol-17 $\beta$ using iodinated tracers and incorporating an affinity chromatography extraction procedure Journal of Steroid Biochemistry 23 1043-1051

Whymann D and Moore RW (1980) Effects of PMSG and the prostaglandin $F_{2 \alpha}$ analogue, cloprostenol, on superovulation, fertilization and egg transport in the ewe Journal of Reproduction and Fertility $60267-272$

Willadsen SM (1979) Embryo transplantation in sheep. In The Management and Diseases of Sheep pp 69-85 Eds JMM Cunningham, JT Stamp and WB Martin. The Commonwealth Agricultural Bureaux, Slough 